\title{
Buffering capacity of cashew soils in South Eastern Tanzania
}

\author{
E.L. Ngatunga ${ }^{1}$, N. Cools ${ }^{2}$, S. Dondeyne ${ }^{1,4}$, J.A. Deckers ${ }^{2} \&$ R. Merckx ${ }^{3}$
}

\begin{abstract}
Cashew soils of South Eastern Tanzania become acidified due to sulphur used for controlling powdery mildew disease (Oidium anacardii Noack). The buffering capacity of surface and subsurface horizons of 35 soil profiles of major cashew growing areas - the Makonde plateau, its piedmont and inland plains - was studied. The buffering capacity of surface and subsurface horizons was strongly correlated with clay content and weakly with organic carbon content. In addition, it was only weakly correlated with total exchangeable bases and available $\mathrm{P}$ of the surface horizon, but strongly with soil $\mathrm{pH}$, base saturation and cation exchange capacity of the clay fraction of the subsurface horizon. Highly weathered sandy soils, dominant on the Makonde plateau and common on the Piedmont, had the lowest buffering capacity. Soils from the inland plains had better buffering capacities as they are generally more clayey or are less weathered. The risk of severe acidification and of a decline in productivity of cashew and of food crops is highest on the Makonde plateau. Further development and dissemination of methods which can reduce the use of sulphur are required.
\end{abstract}

Keywords: Mildews, Oidium, cashews, sulfur, buffering capacity, acidification, soil, Tanzania

\section{INTRODUCTION}

$\mathbf{I}_{\mathrm{f}}^{\mathrm{n}}$ n 1998, cashew ranked second as the most important foreign exchange earning crop in Tanzania being exceeded only by coffee (Bank of Tanzania 1999). Tanzania's production is about 9\% of the world total (FAO 2000). The crop is mostly grown by smallholder farmers and around $70 \%$ of the national production comes from South Eastern Tanzania (Topper et al. 1998). The first reported export of nuts occurred in 1938 when 210 tonnes of raw nuts were shipped to India (Northwood \& Kayumbo 1970). Widespread planting took place after 1945 and a peak production of 145000 tonnes was reached in the 1973/74 marketing season. A catastrophic decline followed, and a record low production of 17060 tonnes was reached in 1990 (FAO 2000). The production decline has been attributed to socioeconomic factors linked to the resettlement programme in the 1970s and to the outbreak of powdery mildew disease, caused by Oidium anarcardii Noack (Martin et al. 1997; Topper et al. 1998). Recent market liberalisation and high nut prices have encouraged farmers to increase production and during the 1999/2000 season 106500 tonnes of nuts were marketed (FAO 2000).

\footnotetext{
${ }^{1}$ Naliendele Agricultural Research Institute, P.O. Box 509, Mtwara, Tanzania.

${ }^{2}$ Institute for Land and Water Management, Katholieke Universiteit Leuven, Vital Decosterstraat 102, B-3000 Leuven, Belgium.

${ }^{3}$ Laboratory for Soil Fertility and Soil Biology, Katholieke Universiteit Leuven, Kardinaal Mercierlaan 92, B-3001 Leuven, Belgium.

${ }^{4}$ Corresponding author
}

In the early 1980s, research at the Naliendele Agricultural Research Institute in Tanzania led to the identification of sulphur as a suitable chemical for controlling powdery mildew disease (Sijaona 1984; Partel 1988). Sulphur has been widely adopted by farmers and during the last three years (1997-1999) sulphur imports to South Eastern Tanzania (regions of Lindi, Mtwara and Tunduru district) went up from 2500 to 7000 tonnes (CBT 1999). The standard recommendation is to dust $1.25 \mathrm{~kg}$ of sulphur per tree per season. For the recommended spacing of $12 \times 12 \mathrm{~m}$ per tree, this is approximately $90 \mathrm{~kg} \mathrm{Sha}^{-1}$. When trees are not dusted, flower buds, flowers, young leaves and young shoots are attacked by the mildew resulting in poor harvest and inferior nut quality. Despite its effectiveness, it was quickly realised that sulphur could have serious environmental consequences. Field surveys indicated that sulphur acidifies soils on which cashew is grown (Majule et al. 1997; Ngatunga et al. 1998). The sustainable production of cashew and intercropped food crops is of major concern.

\section{Soil acidification}

Adverse changes in soil $\mathrm{pH}$ can affect plant growth due to a variety of reasons. As acidity increases, exchangeable calcium decreases and calcium deficiencies may ensue. More important may be the indirect effects as the reduction of available phosphate following fixation with soluble iron and aluminium (Shen et al. 1998). There are also effects on trace elements, particularly the increased solubility of manganese may prove toxic to plants (Robarge \& Johnson 1992). Both fungal and bacterial activity may be curtailed in 
adverse $\mathrm{pH}$ environments, leading to poorer nutrient recycling (Hassett \& Banwaart 1992).

Under moist aerobic conditions sulphur is oxidized to sulphuric acid by autotrophic bacteria, including five species of the genus Thiobacillus (Brady 1990). For every sulphur atom oxidized, two hydrogen ions are formed which may lower soil pH. Nortcliff \& Wong (1995) concluded that the rate of sulphur oxidation depends on the size of the microbial population and factors affecting soil microbial activity such as soil water potential, organic matter content, $\mathrm{pH}$ and temperature. For example, Thiobacillus thiooxidans oxidises elemental sulphur to sulphate and operates optimally between $\mathrm{pH} 3$ and 3.5. Thiobacillus ferrooxidans may also be involved in the transformation of $\mathrm{S}$ into $\mathrm{SO}_{4}{ }^{2-}$ and operates optimally between pH 2 and 3.5 (Rowell 1981). The size of the sulphur particles is important (Weir et al. 1963; Fox et al. 1964). Sulphur powder has a large specific surface area facilitating oxidation. The oxidation rate can be expressed in terms of the surface area exposed and, under optimal conditions, rates of $48-76 \mu \mathrm{g} \mathrm{S} \mathrm{cm}^{-2}$ day ${ }^{-1}$ have been reported (Watkinson 1989). The powdered sulphur applied in Tanzania, has particle sizes smaller than $50 \mu \mathrm{m}$ diameter. If the lower rate reported by Watkinson (1989) is applicable to sulphur used in Tanzania, about $3.2 \mathrm{~kg} \mathrm{Sha}^{-1}$ day ${ }^{-1}$ is oxidized. Hence, it can be assumed that within a year $90 \mathrm{~kg} \mathrm{ha}^{-1}$ will be completely oxidized.

\section{Buffering capacity}

The buffering capacity of a soil is defined as its resistance to changes in $\mathrm{pH}$ when an acid or a base is added. It can be expressed as the quantity of protons required for changing the soil $\mathrm{pH}$ with one unit $\left(\mathrm{mmol} \mathrm{H} \mathrm{kg}^{-1}\right.$ soil $\left.\mathrm{pH}^{-1}\right)$ (Rowell 1994). The buffering capacity of a soil depends among other factors on base status (Magdoff \& Bartlett 1985; Brady 1990), cation exchange capacity (McFee 1983) and presence of weatherable minerals. Soil components that constitute buffering mechanisms also include clay and humic fractions. Buffering at intermediate $\mathrm{pH}$ levels (5.0 to 7.5$)$ is mainly governed by exchange reactions whereby functional groups of organic matter and clay act as sinks for $\mathrm{H}^{+}$and $\mathrm{OH}^{-}(\mathrm{Nielsen}$ et al. 1995; Curtin et al. 1996). If active acidity is neutralized, residual acidity releases $\mathrm{H}^{+}$ions and no change in soil $\mathrm{pH}$ occurs until the reserve of $\mathrm{H}^{+}$is exhausted. Residual acidity is often greater than active acidity, but is less in sandy soils than in clayey soils (Brady 1990). Laboratory methods for evaluating buffering capacity involve potentiometric titration with either an acid or a base (Magdoff \& Bartlett 1985). Field methods involve application of lime and monitoring changes of soil $\mathrm{pH}$ and base saturation.

Predicting the long-term effect of sulphur applications in Tanzania is difficult as the buffering capacity of the cashew soils has never been investigated. In this study, the buffering capacity of soils from 35 cashew groves in six landscape units of South Eastern Tanzania was assessed. The objective was to elucidate the role of physicochemical soil properties in the buffering capacity of the soils and to assess the implications for soil management of current sulphur use in South Eastern Tanzania.

\section{MATERIALS AND METHODS}

Soil samples were taken from 35 profiles in farmers' cashew groves spread over six landscape units, known as major cashew growing areas of South Eastern Tanzania (Figure 1). Results of detailed physical and chemical analysis of the soil profiles were reported by Cools (1998) and are summarized in Table 1. Soil profiles were classified according to

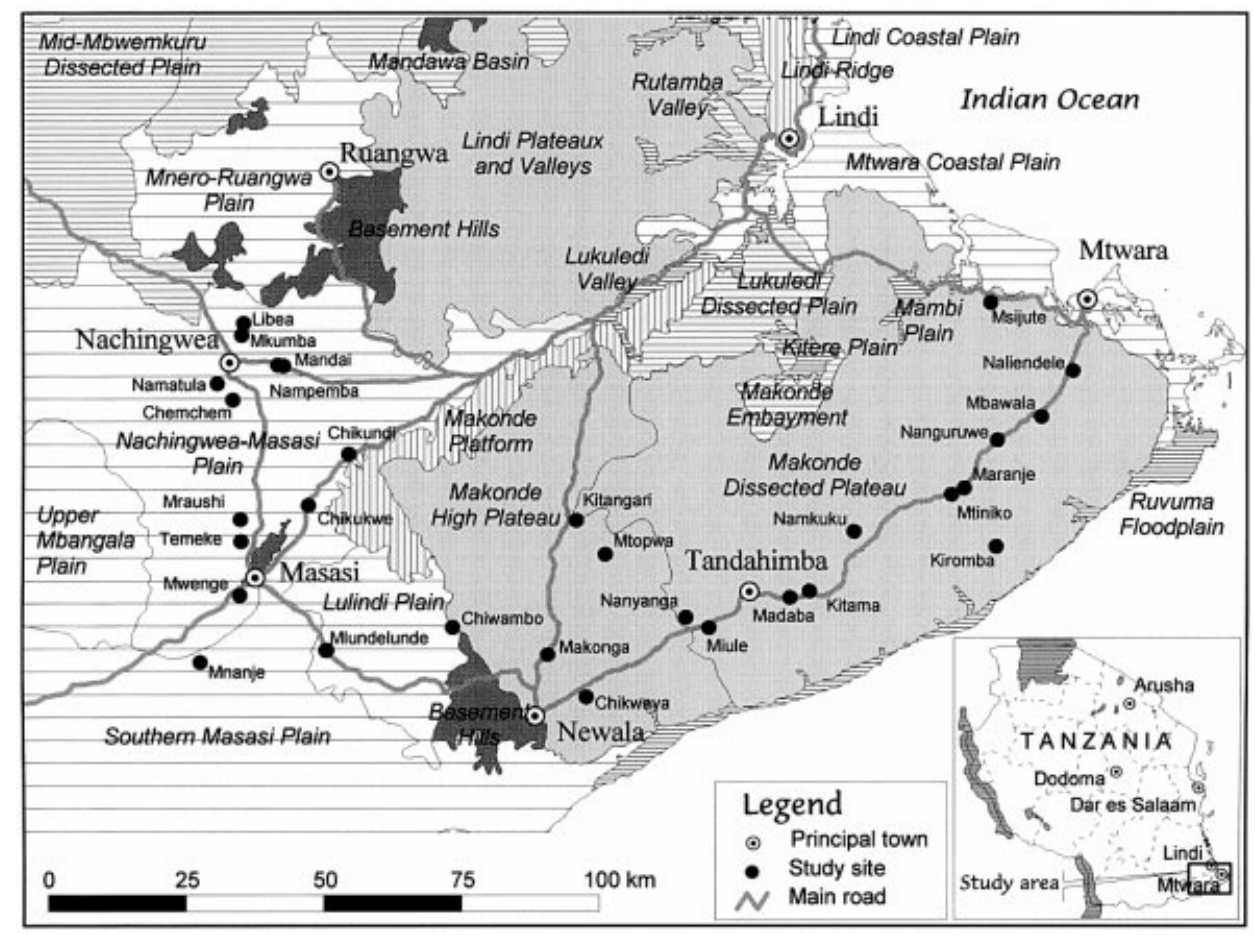

Figure 1. Landscape units of South Eastern Tanzania and location of study sites (adapted from Bennett et al. 1979). 


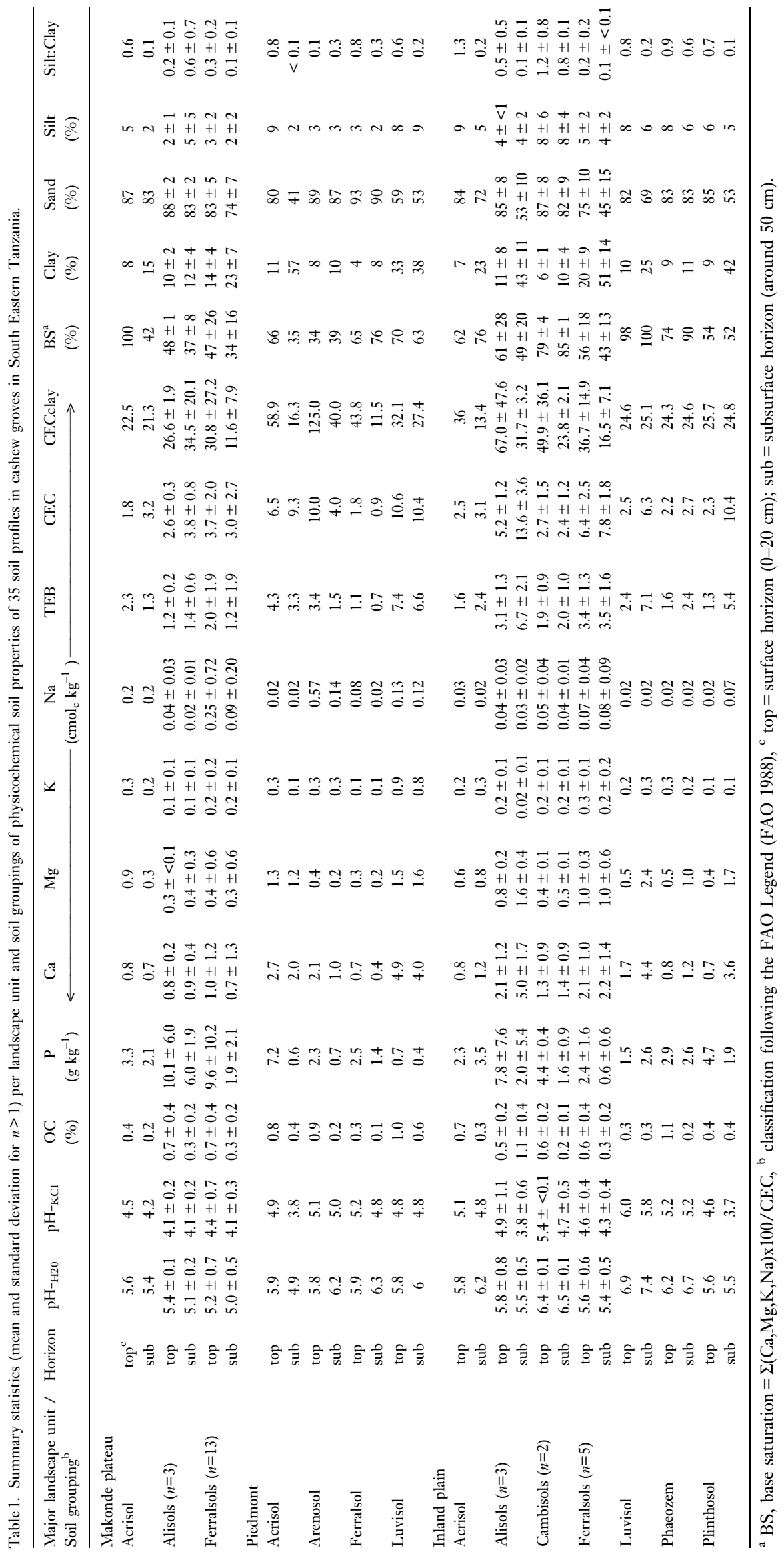


the 'Revised Legend of the Soil Map of the World' (FAO 1988). The statistical analyses were done following the soil groupings defined according to the FAO Legend. Correlations were made with the World Reference Base for Soil Resources - further referred to as WRB - (FAOISRIC-ISSS 1998).

\section{Soils and landscapes}

Soils and landscapes of South Eastern Tanzania were mapped at a reconnaissance scale $(1: 250000)$ by Bennett et al. (1979) (Figure 1). Separated from the Indian Ocean by a narrow coastal plain, plateaux dominate the eastern part of the study area. Of these, the Makonde plateau is the most populated and it produces about $50 \%$ of the cashew nuts from South Eastern Tanzania. The plateau consists of sandy sedimentary deposits of Neogene age on which deep soils are formed, with sandy topsoils and sandy loam or sandy clay loam subsoils. Following the FAO Legend, the dominant soils of the Makonde plateau are Xanthic Ferralsols - or Veti-Acric Ferralsols in World Reference Base (WRB). Most commonly associated soils are Haplic Ferralsols (Lixic and Haplic Ferralsols in WRB) and Haplic Alisols (Profondic Alisols and Arenic Luvisols in WRB). Based on relief characteristics, the plateau has been subdivided into the Makonde High Plateau and the Makonde Dissected Plateau.

Westwards of the plateaux are inland plains which, within the study area, Bennett et al. (1979) mapped as the Lulindi plain, the Nachingwea-Masasi plain and the Southern Masasi plain. These are gently undulating plains with broad flat topped interfluves, wide shallow valleys, formed on PreCambrian Basement rocks, mostly gneiss. Soil changes reflect variations in lithology, drainage and erosional history. On the interfluvial crest, least affected by erosion, typically highly weathered, deep, red, sandy clay loam or sandy clay soils occur. They are Rhodic Ferralsols and Haplic Acrisols according to the FAO Legend or Veti-Acric Ferralsols and Profondic Acrisols according to WRB. On the slopes, a variety of less weathered, often shallow soils occur. Most common soil units are Rhodic Luvisols and Chromic Cambisols (Rhodic and Chromic Luvisols, Mollic and Rhodi-Bathileptic Cambisols in WRB). Gleyic Alisols and Albic Plinthosols (Gleyic Luvisols and Endoeutric Plinthosols in WRB) occur in the valleys, while Ferralic and Luvic Arenosols (FAO Legend as well as WRB) are common on the Piedmont of the Makonde plateau.

\section{Buffering capacity}

Buffering capacity was examined for the surface horizon (0$20 \mathrm{~cm}$ ) and the subsurface horizon at around $50 \mathrm{~cm}$. Twenty grams of fine earth (less than $2 \mathrm{~mm}$ ) of each sample was placed in $100 \mathrm{ml}$ glass bottles to which $50 \mathrm{ml}$ of distilled water was added as for standard soil $\mathrm{pH}$ measurements. Sulphuric acid was added to these bottles as 0 (reference), $0.5,1$ and $2 \mathrm{ml}$ of $0.015 \mathrm{M} \mathrm{H} \mathrm{H}_{2} \mathrm{SO}_{4}$. These additions represented $0,0.75,1.5$ and $3 \mathrm{mmol} \mathrm{H}^{+} \mathrm{kg}^{-1}$ soil. The bottles were shaken for 30 minutes after which a first $\mathrm{pH}$ measurement was made; a second measurement was made after 24 hours.
The concentrations of added acid were based on the rationale that for every sulphur atom, two hydrogen ions are formed. If sulphur is applied according to the recommendation of $90 \mathrm{~kg} \mathrm{ha}^{-1}$, it can be calculated that an amount of $5.6 \mathrm{kmol} \mathrm{H}^{+} \mathrm{ha}^{-1}$ is added annually. For the upper $20 \mathrm{~cm}$ of

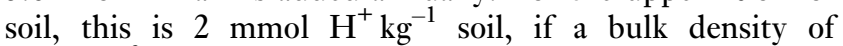
$1.4 \mathrm{~g} \mathrm{~cm}^{-3}$ is assumed.

\section{Statistical analysis}

Pearson correlation coefficients, with two tailed levels of significance, were calculated to identify relationships between buffering capacity and physicochemical soil properties. The buffering capacity is calculated as the quantity of protons added $\left(3 \mathrm{mmol} \mathrm{H}^{+} \mathrm{kg}^{-1}\right.$ soil $)$ divided by $\Delta \mathrm{pH}$, with $\Delta \mathrm{pH}=\mathrm{pH}\left(0 \mathrm{mmol} \mathrm{H} \mathrm{kg}^{-1}\right.$ soil $)-\mathrm{pH}\left(3 \mathrm{mmol} \mathrm{H}^{+} \mathrm{kg}^{-1}\right.$ soil $)$.

The effect on the $\Delta \mathrm{pH}$ of the quantity ' $\mathrm{H}^{+}$added' (random factor with four levels), sampling depth (fixed factor with two levels $0-20$ and $50 \mathrm{~cm}$ ), time (random factor with two levels $0.5 \mathrm{~h}$ and $24 \mathrm{~h}$ ), landscape unit (fixed factor with six levels) and soil groupings (fixed factor with nine levels) was analysed with a variance analysis of repeated measures. The procedure adopted was the PROC MIXED of the statistical package SAS (Littell et al. 1996). The PROC MIXED model takes into account both fixed and random effects as listed above. Multiple pairwise comparisons of the least square means derived from the PROC MIXED model, were made for the 'Landscape units' and 'Soil groupings' with the Tukey-Kramer procedure. This way, groups of 'Landscape units' and 'Soil groupings' whose least square means of $\mathrm{pH}$ do not differ from the single degree of freedom test at $95 \%$ level of probability, were identified.

\section{RESULTS AND DISCUSSION}

\section{Titration curves}

The titration curves in Figure 2 illustrate two examples from the Makonde plateau and two from the inland plains. The examples from the plateau had a more acidic initial soil $\mathrm{pH}$ than those of the inland plains. They also had markedly larger $\Delta \mathrm{pH}$. The $\mathrm{pH}$ measured after $24 \mathrm{~h}$ was higher than after 30 minutes, but the increase was more pronounced for the soils of the plains. The buffering capacities derived from the titrations are presented in Table 2. The buffering capacity of these tropical soils is about 10 times lower than those of a range of British soils reported by Rowell (1994).

\section{Buffering capacity in relation to soil properties}

The correlation coefficients (with $P<0.1$ ) are presented in Table 3. The buffering capacity of the surface horizon measured after 30 minutes showed a significant positive linear relationship with the clay content and, reciprocally, a negative relationship with the sand content. In the subsurface horizon the silt content and especially the silt:clay ratio is negatively related to the buffering capacity, but this is difficult to interpret as absolute silt contents were very low (Table 1). Higher organic carbon contents are positively correlated with higher buffering capacity. These observations support earlier findings by Rowell (1981) and Van Breemen et al. (1984), who showed that the buffering 

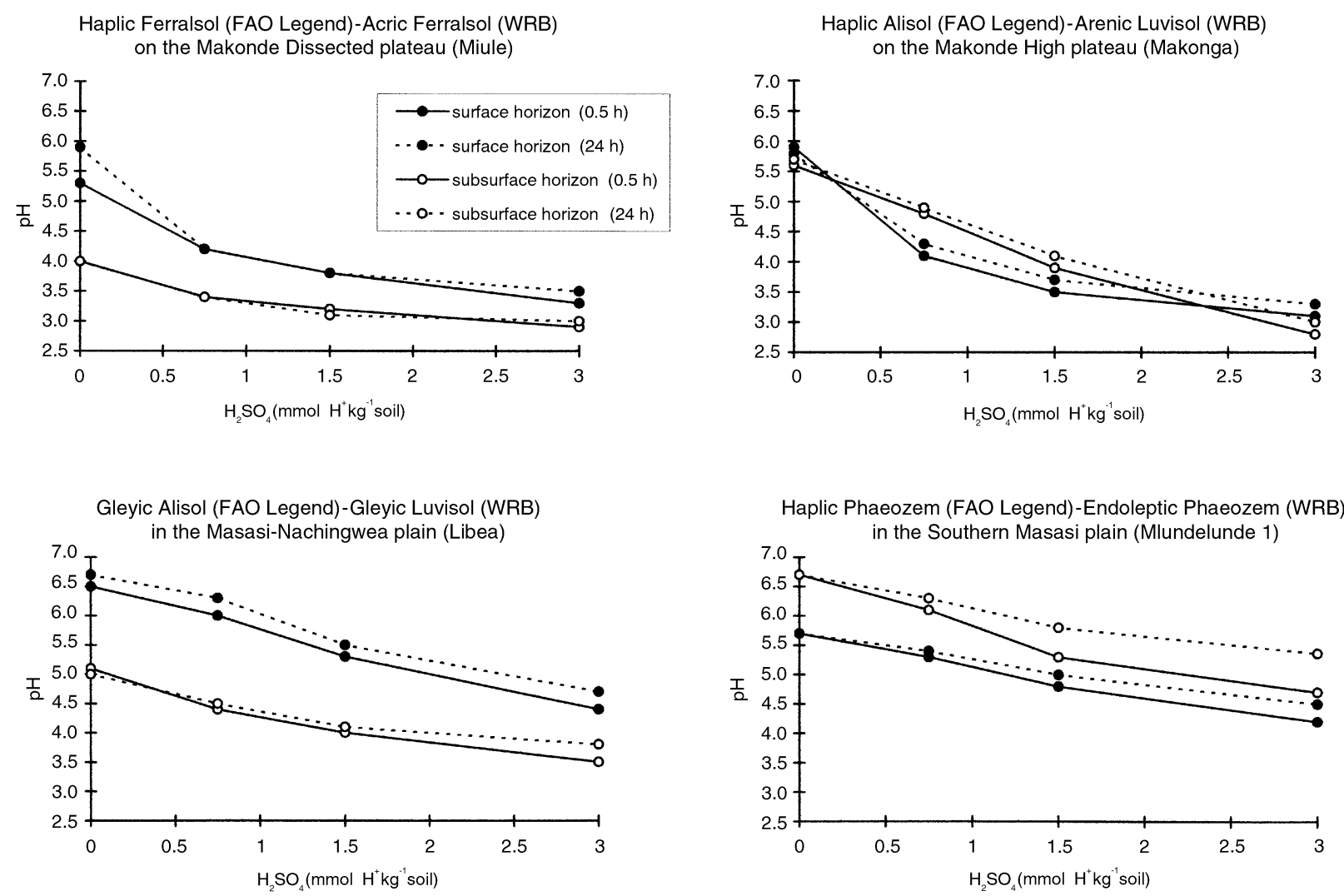

Figure 2. Titration curves of two profiles from the Makonde plateau and two from the inland plains.

capacity lies in the exchange capacity of the clay and the organic matter content of the soil. Although the relationship is weaker, this also explains the correlation found with the CEC (cation exchange capacity) of the soil.

For the divalent exchangeable bases $\left(\mathrm{Ca}^{2+}\right.$ and $\left.\mathrm{Mg}^{2+}\right)$ and the available $\mathrm{P}$ only a weak correlation was found for the surface horizon. As the $\mathrm{pH}$ of the soil profiles were in the acidic range, exchangeable bases are bound to the exchange complex provided by the organic matter, the clay fraction or sesquioxides. As the buffering capacity seems only to relate with these elements in the surface horizon, this could indicate an exchange reaction of $\mathrm{H}^{+}$with these elements bound to humic substance of the Ah horizon.

The high correlation between the buffering capacity and the initial $\mathrm{pH}$ of the subsurface horizon means that more acidic soils are better buffered than the less acidic ones. Magdoff \& Bartlett (1985) and Godefroy \& Dormoy (1990) have reported similar findings, namely that soils are poorly buffered between $\mathrm{pH} 4.5$ and 6.5 and well buffered below $\mathrm{pH}$ 4. They further stated that soils are well buffered above $\mathrm{pH} 7$. Since there are no profiles in this study with $\mathrm{pH}$ values exceeding this range, this could not be verified. Base saturation and the CEC of the clay fraction (CECclay) seem to be linked to this phenomenon. Low $\mathrm{pH}$, base saturation and CECclay are typical of some highly weathered soils. At first sight this could paradoxically lead to the conclusion that highly weathered soils have a better buffering capacity than poorly weathered soils. However, the correlation coefficient between the buffering capacity and initial $\mathrm{pH}\left(\mathrm{H}_{2} \mathrm{O}\right)$,
$\mathrm{pH}(\mathrm{KCl})$ and $\mathrm{BS}$ (base saturation) was less strong with the measurement done after $24 \mathrm{~h}$, while the coefficient with the clay content and the CEC increased. Dissolution of primary soil minerals can be assumed after which protons are absorbed on the exchange complex. This may explain the increase in $\mathrm{pH}$ after $24 \mathrm{~h}$, as illustrated by the soils from the inland plains in Figure 2, and results in a better buffering capacity.

\section{Buffering capacity in relation to landscape units and soil groupings}

Results of the variance analysis of factors contributing to the $\mathrm{pH}$ are presented (Table 4). The factors 'Landscape unit', horizon 'Depth', quantity ' $\mathrm{H}^{+}$added', 'Time' and 'Soil groupings' contributed significantly to the model. However, as significant interactions were found between the factors 'Landscape unit', 'Depth' and ' $\mathrm{H}^{+}$added' on the one hand and 'Soil groupings' on the other, the model was split into two new models containing four non-interacting factors each. Model 1 contained the factors 'Landscape unit', 'Depth', ' $\mathrm{H}^{+}$added' and 'Time' and Model 2 contained the factors 'Soil groupings', 'Depth', ' $\mathrm{H}^{+}$added' and 'Time'. In these models the factor 'Time' is less significant.

The results of the family of pairwise tests of the landscape units (Model 1) and of the soil groupings (Model 2) are presented in a line plot in Figure 3. On the left hand side, landscape units with least square means that do not differ $(P<0.05)$ are grouped together. Similarly, on the 
Table 2. Buffering capacities (BC in mmol $\mathrm{H}^{+} \mathrm{kg}^{-1} \mathrm{pH}^{-1}$ ) of 35 soil profiles in cashew groves in South Eastern Tanzania measured 30 minutes and $24 \mathrm{~h}$ after addition of sulphuric acid.

\begin{tabular}{|c|c|c|c|c|c|}
\hline \multirow{2}{*}{$\begin{array}{l}\text { Landscape unit } \\
\text { Soil unit }^{\mathrm{a}}\end{array}$} & \multirow[b]{2}{*}{ Profile } & \multicolumn{2}{|c|}{ Surface horizon $(0-20 \mathrm{~cm})$} & \multicolumn{2}{|c|}{ Subsurface horizon (around $50 \mathrm{~cm}$ ) } \\
\hline & & $\mathrm{BC}_{30 \mathrm{~min}}$ & $\mathrm{BC}_{24 \mathrm{~h}}$ & $\mathrm{BC}_{30 \min }$ & $\mathrm{BC}_{24 \mathrm{~h}}$ \\
\hline \multicolumn{6}{|c|}{ Makonde Dissected plateau } \\
\hline Haplic Acrisol & Nanguruwe & 1.3 & 1.3 & 1.8 & 1.7 \\
\hline Haplic Alisol & Madaba & 1.2 & 1.3 & 1.4 & 1.3 \\
\hline Haplic Ferralsol & Miule & 1.5 & 1.3 & 2.7 & 3.0 \\
\hline " & Mtiniko & 1.9 & 1.9 & 1.3 & 1.4 \\
\hline$"$ & Msijute & 2.7 & 2.7 & 1.3 & 1.4 \\
\hline Rhodic Ferralsol & Naliendele & 1.6 & 1.5 & 2.0 & 2.3 \\
\hline Xanthic Ferralsol & Kiromba & 1.6 & 1.7 & 2.1 & 2.3 \\
\hline$"$ & Maranje & 2.0 & 2.0 & 2.1 & 2.0 \\
\hline$”$ & Mbawala & 2.0 & 2.1 & 1.5 & 2.5 \\
\hline$”$ & Namkuku & 2.0 & 2.0 & 3.0 & 2.7 \\
\hline$”$ & Kitama & 2.3 & 3.0 & 1.6 & 2.0 \\
\hline$"$ & Nanyanga & 2.3 & 2.5 & 2.5 & 2.5 \\
\hline \multicolumn{6}{|l|}{ Makonde High plateau } \\
\hline Haplic Alisol & Makonga & 1.1 & 1.2 & 1.1 & 1.1 \\
\hline$"$ & Kitangari & 1.6 & 1.8 & 2.0 & 2.5 \\
\hline Haplic Ferralsol & Mtopwa & 2.5 & 2.3 & 2.5 & 3.3 \\
\hline Rhodic Ferralsol & Chikwaya & 3.8 & 10.0 & 0.9 & 1.3 \\
\hline Xanthic Ferralsol & Chiwambo5 & 2.0 & 2.0 & 2.3 & 2.7 \\
\hline \multicolumn{6}{|l|}{ Piedmont } \\
\hline Haplic Acrisol & Chikundi & 2.5 & 3.3 & 4.3 & 5.0 \\
\hline Ferralic Arenosol & Chiwambo3 & 1.4 & 1.6 & 1.1 & 1.1 \\
\hline Plinthic Ferralsol & Chikukwe & 0.9 & 1.0 & 1.0 & 1.3 \\
\hline Chromic Luvisol & Chiwambo2 & 2.0 & 2.3 & 2.0 & 2.1 \\
\hline \multicolumn{6}{|c|}{ Nachingwea Masasi plain } \\
\hline Albic Plinthosol & Temeke & 1.4 & 2.0 & 2.5 & 2.7 \\
\hline Eutric Cambisol & Chemchem & 1.3 & 1.4 & 1.2 & 1.3 \\
\hline Gleyic Alisol & Libea & 1.4 & 1.5 & 1.9 & 2.5 \\
\hline Haplic Alisol & Nampemba & 1.6 & 1.9 & 2.7 & 3.8 \\
\hline Humic Cambisol & Mwenge & 1.8 & 1.9 & 1.0 & 1.3 \\
\hline Rhodic Ferralsol & Mkumba & 1.3 & 1.8 & 3.8 & 5.0 \\
\hline$"$ & Namatula & 1.9 & 2.3 & 1.4 & 2.1 \\
\hline$”$ & Mandai & 2.7 & 4.3 & 2.7 & 4.3 \\
\hline$”$ & Mraushi & 2.7 & 2.7 & 3.3 & 3.8 \\
\hline \multicolumn{6}{|l|}{ Southern Masasi plain } \\
\hline Haplic Acrisol & Mnanje & 1.4 & 1.9 & 1.3 & 1.8 \\
\hline \multicolumn{6}{|l|}{ Lulindi plain } \\
\hline Chromic Luvisol & Mlundelunde2 & 1.4 & 1.8 & 1.1 & 1.8 \\
\hline Gleyic Alisol & Chiwambol & 1.3 & 1.4 & 1.4 & 1.4 \\
\hline Haplic Phaeozem & Mlundelunde1 & 2.0 & 2.5 & 1.5 & 2.2 \\
\hline Rhodic Ferralsol & Chiwambo4 & 1.4 & 1.8 & 2.0 & 2.1 \\
\hline
\end{tabular}

${ }^{a}$ classification following FAO Legend (FAO 1988).

right hand side groups of 'Soil groupings' are presented. This analysis results in a ranking of landscape units (Model 1) and soil groupings (Model 2) in terms of their buffering capacity.

The Makonde Dissected Plateau (Group $\mathrm{L}_{1}$, Figure 3), followed by the Makonde High Plateau and the Piedmont (Group $\mathrm{L}_{2}$ ) have the lowest buffering capacity. Soils of the inland plains have on average higher buffering capacities (groups $\mathrm{L}_{4}$ and $\mathrm{L}_{5}$ ). The Piedmont is placed in both Group $\mathrm{L}_{2}$ and $\mathrm{L}_{3}$, which reflects the heterogeneity of the soils of this unit; soils are partly derived from sandy colluvium from the Makonde Plateau, partly from Pre-Cambrian Basement material.

A similar analysis applied to the soil groupings (Model 2) resulted in three groups (Figure 3), and reveals the complexity of the inland plains. Soils with the lowest buffering capacity are Ferralsols, Arenosols (Group $\mathrm{S}_{1}$ ) and Alisols and Plinthosols (Group $S_{1} / S_{2}$ in Figure 3). Light textured Ferralsols and Arenosols are typical for the Makonde plateau and its piedmont. But Ferralsols, Alisols and Plinthosols are also common in the plains. The soils with largest buffering capacities, Cambisols, Luvisols and Phaeozems (Group $\mathrm{S}_{3}$ ), are typically found in the plains. These soils have moderate contents of organic carbon, of exchangeable bases and moderate cation exchange capacity which provide better buffering capacity.

In both models there was a significant contribution of the factor 'Depth'. Buffering capacity of the subsurface horizon is usually better than that of the surface horizon, which has to be attributed to the greater clay content. In the surface horizon organic matter plays a relatively greater role as a sink for $\mathrm{H}^{+}$. 
Table 3. Pearson correlation coefficients between buffering capacity (BC) and physicochemical properties of 35 soil profiles in cashew groves. The $\mathrm{BC}$ was measured 30 minutes and $24 \mathrm{~h}$ after addition of sulphuric acid

\begin{tabular}{|c|c|c|c|c|}
\hline \multirow[t]{2}{*}{ Soil property } & \multicolumn{2}{|c|}{$\begin{array}{l}\text { Surface horizon } \\
\quad(0-20 \mathrm{~cm})\end{array}$} & \multicolumn{2}{|c|}{$\begin{array}{l}\text { Subsurface horizon } \\
\text { (around } 50 \mathrm{~cm} \text { ) }\end{array}$} \\
\hline & $\mathrm{BC}_{30 \min }$ & $\mathrm{BC}_{24 \mathrm{~h}}$ & $\mathrm{BC}_{30 \min }$ & $\mathrm{BC}_{24 \mathrm{~h}}$ \\
\hline Sand & -0.47 ***** & $-0.36^{* *}$ & $-0.56^{* * * * *}$ & $-0.65 * * * * *$ \\
\hline Clay & $0.47^{* * * * *}$ & $0.34 * *$ & $0.63^{* * * * * *}$ & 0.71 ****** \\
\hline Silt & - & - & $-0.36^{* * *}$ & - \\
\hline Silt/Clay & - & - & $-0.47 * * *$ & $-0.46^{* * * *}$ \\
\hline $\mathrm{OC}^{\mathrm{a}}$ & $0.36^{* * *}$ & - & $0.31^{*}$ & $0.30 *$ \\
\hline $\mathrm{P}$ & $0.47 * * * *$ & $0.49^{* * * *}$ & - & - \\
\hline $\mathrm{Ca}$ & $0.31^{*}$ & - & - & - \\
\hline $\mathrm{Mg}$ & $0.39^{* * *}$ & $0.30^{*}$ & - & - \\
\hline K & - & - & - & - \\
\hline $\mathrm{Na}$ & - & - & - & - \\
\hline $\mathrm{TEB}^{\mathrm{b}}$ & $0.31^{*}$ & - & - & - \\
\hline CEC & $0.36^{* *}$ & - & - & $0.32^{*}$ \\
\hline CECclay & - & - & $-0.33^{*}$ & $-0.33^{*}$ \\
\hline $\mathrm{BS}^{\mathrm{c}}$ & - & - & $-0.54 * * *$ & -0.47 **** \\
\hline $\mathrm{pH}-\mathrm{H}_{2} \mathrm{O}$ & - & - & $-0.62 * * * * *$ & -0.51 **** \\
\hline pH-KCl & - & - & $-0.55^{* * * *}$ & $-0.43^{* *}$ \\
\hline
\end{tabular}

two tailed levels of significance: $-P \geqslant 0.1 ;{ }^{*} P<0.1$; ** $P<0.05$; *** $P<0.01$; ***** $P<0.001$

${ }^{\mathrm{a}} \mathrm{OC}=$ organic carbon ${ }^{\mathrm{b}} \mathrm{TEB}=$ total enchangeable bases ${ }^{\mathrm{c}} \mathrm{BS}=$ Base saturation

\section{Implications for soil management}

Assuming that all sulphur dusted enters the soil, four years of dusting is likely to cause a $\mathrm{pH}$ decline between 0.3 and 3.1 $\mathrm{pH}$ units in the surface horizon and between 0.6 and $2.7 \mathrm{pH}$ units in the subsurface horizon. These $\mathrm{pH}$ changes are similar to the field observations made by Majule et al. (1997) and Ngatunga et al. (1998). Although cashew trees develop deep rooting systems and tolerate low $\mathrm{pH}$ levels, concerns for their long-term productivity seem justified. Moreover, Smith et al. (1995) demonstrated that about $80 \%$ of the sulphur drifts away, which may have important consequences for intercrops such as maize, sorghum, cowpea and finger millet.

As soils of the Makonde plateau have the lowest buffering capacity, alternative approaches for controlling the powdery mildew disease are most pressing here. Liming, cultural practices which reduce the incidence of the disease, or organic fungicides are the basic options as long as resistant varieties are not widely available. To neutralize $90 \mathrm{~kg} \mathrm{Sha}^{-1}$, about $200 \mathrm{~kg} \mathrm{Ca}(\mathrm{OH})_{2} \mathrm{ha}^{-1}$ is required. Although this is locally available as burnt coral lime, such quantities would be financially prohibitive for smallholder farmers and its widespread use would be detrimental to the marine environment. Fossil coral lime, available in the coastal plain and not yet exploited, would be a better alternative. Much less sulphur would be needed, and much less lime would be required, if the incidence of the powdery mildew disease could be suppressed by cultural practices as demonstrated by Kasuga et al. (1998) and by Nathaniels (1998). To achieve this would require a large involvement of extension staff as these techniques require farmers to understand aspects of the epidemiology of the disease. The water based organic fungicides hexaconazole, triadimenol and penconazole, have proven effective for controlling
Table 4. Variance analysis of factors contributing to changes in $\mathrm{pH}$ upon addition of $\mathrm{H}_{2} \mathrm{SO}_{4}$ to samples from 35 soil profiles under cashew.

\begin{tabular}{lrc}
\hline Factor & F-value & Probability \\
\hline Overall model & & \\
$\quad$ Landscape unit & 16.11 & $<0.001$ \\
Depth & 50.09 & $<0.001$ \\
$\mathrm{H}^{+}$added & 721.44 & $<0.001$ \\
Time & 8.61 & $<0.01$ \\
Soil grouping & 12.66 & $<0.001$ \\
Landscape unit $\times$ Soil grouping & 18.02 & $<0.001$ \\
Depth $\times$ Soil grouping & 8.85 & $<0.001$ \\
$\mathrm{H}^{+}$added $\times$Soil grouping & 2.08 & $<0.05$ \\
Time $\times$ Soil grouping & 0.35 & 0.944 \\
Model 1 & & \\
Landscape unit & 35.14 & $<0.001$ \\
Depth & 44.09 & $<0.001$ \\
$\mathrm{H}^{+}$added & 250.00 & $<0.001$ \\
Time & 5.67 & $<0.05$ \\
Model 2 & & \\
Soil grouping & 48.42 & $<0.001$ \\
Depth & 64.76 & $<0.001$ \\
$\mathrm{H}^{+}$added & 822.03 & $<0.001$ \\
Time & 8.30 & $<0.01$ \\
\hline
\end{tabular}

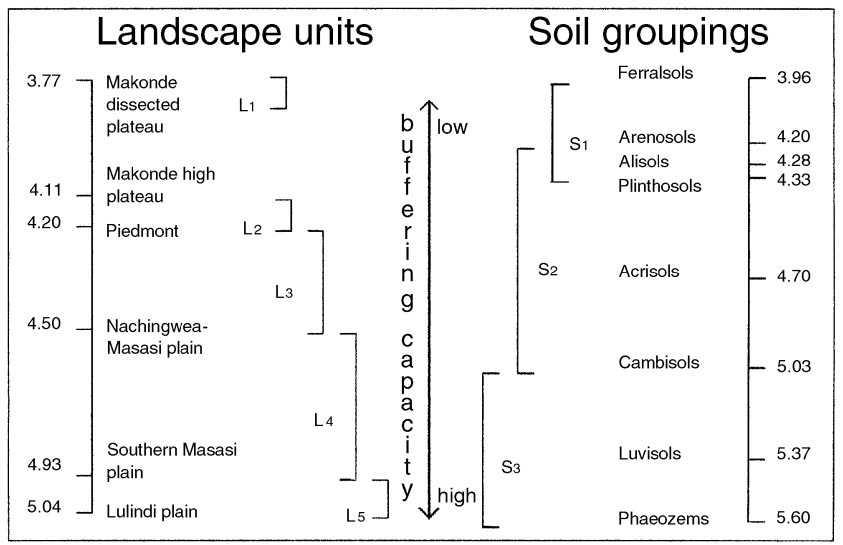

Figure 3. Line plot of least square means $(\mathrm{pH})$ indicating non-significant difference $(P \leqslant 0.05)$ between landscape units and soil groupings in relation to buffering capacity.

powdery mildew disease (Smith et al. 1998). They have the disadvantage of costing more than sulphur and of being more toxic to humans and animals (Tomlin 1994). Moreover, they are applied in water which is scarce on the Makonde plateau.

\section{CONCLUSIONS}

The buffering capacity of cashew soils is determined by the clay content, organic carbon content and the weathering status. Soils of the Makonde plateau, where about $50 \%$ of the cashew nuts from South Eastern Tanzania are produced, are the most susceptible to soil acidification. Overall, soils of the plains have a higher buffering capacity but the situation is more complex as soils are more diverse. In the long run, acidification due to sulphur is likely to reduce the productivity of both cashew trees and food crops. Further 
development and dissemination of techniques which can reduce the use of sulphur are therefore urgently needed.

\section{ACKNOWLEDGEMENTS}

This study was made possible thanks to the Tanzanian Agricultural Research Fund and the Cashew Research Fund with additional support from the Belgian Administration for Development Co-operation. We would like to thank Musa Mapua, Musa Dalis and Musa Mumina for their assistance during the fieldwork and in the laboratory. Special thanks are due to the numerous farmers for their kind cooperation.

\section{REFERENCES}

Bank of Tanzania 1999. Economic Bulletin for the Quarter ended $31^{\text {st }}$ March 1999. Central Bank of Tanzania, Dar es Salaam.

Bennett JG Brown LC Geddes AMW Hendy CRC Lavelle AM Sewell LG \& Rose Innes R 1979. Mtwara/Lindi Regional Integrated Development Programme, Report of the zonal survey team in phase 2, Vol. 1, The physical environment. Land Resources Development Centre, Surrey.

Brady NC 1990. The nature and properties of soils. Macmillan Publishing Company, Inc., New York.

CBT 1999. Cashew Board of Tanzania, Annual report 1999. Ministry of Agriculture and Co-operatives, Mtwara.

Cools N 1998. Geographical analysis of risk for soil acidification due to sulphur dusting on cashew trees in Tanzaniaśs southern zone. MSc dissertation Katholieke Universiteit Leuven.

Curtin D Campbell C \& Meer D 1996. Prediction of titratable and soil sensitivity to $\mathrm{pH}$ change. Journal of Environmental Quality 25, 12801284.

FAO 1988. FAO-Unesco Soil Map of the World, revised legend, with corrections. World Resources Report 60 FAO, Rome.

FAO 2000. FAO Statistical Database, domain Agricultural Production. URL:http://apps.fao.org/default.htm. Update of 5 April 2000. FAO, Rome.

FAO-ISRIC-ISSS 1998. World Reference Base for Soil Resources. World Soil Resources Reports No 84, FAO, Rome.

Fox RL Atesolp HM Kambell DH \& Rhodes HF 1964. Factors influencing the availability of sulphur fertilisers to alfalfa and corn. Soil Science Society of America Proceedings 28, 406-408.

Godefroy J \& Dormoy M 1990 Stimulation de l'action du chaulage sur le $\mathrm{pH}$ et les teneurs en aluminium et en manganese dans un ferrisol de Martinique. Fruits 45, 219-222.

Hassett JJ \& Banwaart WL 1992. Soils and their environment. PrenticeHall, Englewood Cliffs, New Jersey.

Kasuga LJ Topper CP Martin PJ Boma F de Waal D \& Bakari JJ 1998. Integrated cashew management: appropriate strategies for increasing the productivity of smallholder cashew. In: Proceedings of the International Cashew and Coconut Conference - Trees for life, the key to development, eds CP Topper, DS Calligari et al., BioHybrids International, Reading pp 71-75.

Littell RC Milliken GA Stroup WW \& Wolfinger RD 1996. SAS for Mixed Models. Cary, North Carolina, SAS Institute Inc.

Magdoff FR \& Bartlett RJ 1985. Soil pH buffering revisited. Soil Science Society America 49, 145-148.

Majule AE Topper CP \& Nortcliff S 1997. The environmental effects of dusting cashew (Anacardium occidentale L.) trees with sulphur in southern Tanzania. Tropical Agriculture 74, 25-33.

Martin PJ Topper CP Bashiru RA Boma F de Waal D Harries HC Kasuga LJ Katinila N Kikotoka LP Lamboll R Maddison AC Majule AE Masawe PA Millanzi KJ Nathaniels NQ Shomari SH Sijaona ME \&
Stathers T 1997. Cashew nut production in Tanzania: constraints and progress through integrated crop management. Crop Protection 16, 5-14. McFee WW 1983. Sensitivity ratings of soils to acid deposition. A review. Environmental Experimental Botany 23, 203-210.

Nathaniels N 1998. Self help, cashew trees and learning in rural primary schools, Nachingwea district, Tanzania. Forest, Trees and People Newsletter 35, 9-13.

Ngatunga EL Dondeyne S \& Deckers JA 1998. One decade of sulphur dusting in South Eastern Tanzania: effects on soil pH. In: Proceedings of the International Cashew and Coconut Conference - Trees for life, the key to development, eds CP Topper, DS Calligari et al., BioHybrids International, Reading pp 64-70.

Nielsen D Hoyt PB Parchomchuk P Nielsen G \& Hogue EJ 1995. Measurements of the sensitivity of orchard soil to acidification. Canadian Journal of Soil Science 75, 391-395.

Nortcliff S \& Wong M 1995. A review of the effects of sulphur additions on acid tropical soils, with particular emphasis on the soils of the ODA Cashew Research Project, Naliendele A.R.I., Tanzania \& University of Reading.

Northwood PJ \& Kayumbo H 1970. Cashew production in Tanzania. World Crops 22, 88-91.

Partel L 1988. Programma anacardio: un contributo italiano al rilancio della coltura in Tanzania. Rivista di Agricoltura Subtropicale e Tropicale, Instituto Agronomico per l'Otremare, Firenze 4, 631-645.

Robarge WP \& Johnson DW 1992. The effects of acidic deposition on forested soils. Advances in Agronomy 47, 1-83.

Rowell DL 1981. Oxidation and reduction. In: The chemistry of soil processes, eds DJ Greenland \& MHB Hayes, John Wiley and Sons, Chichester pp 101-462.

Rowell DL 1994. Soil science: methods and applications. Longman Scientific and Technical, Harlow.

Shen S Gary EP Hassett JJ \& Stucki JW 1998. Acidity and aluminium toxicity caused by iron oxidation around anode bars. Soil Science 163, $657-664$.

Sijaona MER 1984. Investigations into effectiveness of sulphur against Oidium anacardii (Noack) on five cashew trees at Naliendele. Rivista di Agricultura Subtropicale e Tropicale 78, 199-209.

Smith DN King WJ Topper CP Boma F \& Cooper JF 1995. Alternative techniques for the application of sulphur to cashew trees for the control of powdery mildew caused by the fungus Oidium anacardii in Tanzania. Crop Protection 14, 550-560.

Smith DN Topper CP \& Cooper JF 1998. Comparison and evaluation of alternative methods for the application of fungicides to cashew trees for the control of powdery mildew disease. In: Proceedings of the international cashew and Coconut Conference - Trees for life, the key to development, eds CP Topper, DS Calligari et al., BioHybrids International, Reading pp 282-285.

Tomlin C (ed.) 1994. The pesticide manual. Incorporating the agrochemical handbook. $10^{\text {th }}$ edition. The British Crop Protection Council and the Royal Society of Chemistry.

Topper CP Martin PJ Katinila N Kikoka LP Lamboll R Masawe PAL \& Shomari SH 1998. The historical and institutional background of the Tanzanian cashew industry. In: Proceedings of the international cashew and Coconut Conference - Trees for life, the key to development, eds CP Topper, DS Calligari et al., BioHybrids International, Reading pp 76-83. Van Breemen N Driscoll CT \& Mulder J 1984. Acid deposition and internal proton sources in acidification of soils and waters. Nature 307, 599-604.

Watkinson IH 1989. Measurements of the oxidation rate of elemental sulphur. Australian Journal of Experimental Agriculture and Animal Husbandry 27, 365-375.

Weir RG Garkus B \& Atkison WT 1963. The effect of particle size on the availability of brimstone sulphur to white clover. Australian Journal of Experimental Agriculture and Animal Husbandry 3, 314-318.

Received September 2000, accepted after revision January 2001. 